\title{
GETHOK TULAR, POLA KOMUNIKASI GERAKAN SOSIAL BERBASIS KEARIFAN LOKAL MASYARAKAT SAMIN DI SUKOLILO
}

\author{
Rini Darmastuti, Atwar Bajari, Haryo S. Martodirdjo, dan Eni Maryani \\ Universitas Kristen Satya Wacana Jalan Diponegoro 52-60 Satiga 50711, Telp 0298321212 \\ Universitas Padjajaran Jalan Raya Sumedang Jawa Barat \\ Email: Rindarmas@yahoo.com
}

\begin{abstract}
The social movement that strongly opposed the construction of cement plant in Sukolilo, Pati, Central Java constitutes a unique social movement. This movement, which is known as protest action, was conducted in a non violent way. One of the ways to embrace people in Sukolilo is by using communication strategy, called as 'gethok tular'. This is a communication strategy based on local wisdom owned by Samin community. In its growth, gethok tular has formed communication pattern in Samin's social movement. The communication pattern of gethok tular is in the form of informal communication. This paper was based on the result of constructivist research using ethnography of communication approach. Direct and in-depth interviews were employed to collect data.
\end{abstract}

Keywords: Gethok tular, Communication Pattern, Social Movement, Local Wisdom, Samin Community

\begin{abstract}
Abstrak
Gerakan sosial dalam rangka menolak pembangunan pabrik semen yang ada di Sukolilo, Pati, Jawa Tengah merupakan gerakan sosial yang unik. Gerakan yang terkenal dengan sebutan aksi tolak ini dilakukan dengan cara damai. Penelitian ini bertujuan menemukan pola komunikasi gerakan sosial berbasis kearifan lokal masyarakat Samin di Sukolilo. Penelitian ini menggunakan pendekatan konstruktivis dengan metode etnografi komunikasi. Pengumpulan data dilakukan dengan menggunakan observasi secara langsung dan wawancara mendalam. Hasil penelitian ini menemukan pola komunikasi "Gethok Tular" yang digunakan untuk merangkul masyarakat yang ada di Sukolilo. Strategi komunikasi tersebut berdasarkan kearifan lokal masyarakat Samin. Strategi komunikasi "Gethok Tular" dalam perkembangannya membentuk pola komunikasi dalam gerakan social dalam menolak rencana pendirian pabrik Semen di Sukolilo.
\end{abstract}

Kata kunci: Gethok Tular, Pola Komunikasi, Gerakan Sosial, Kearifan Lokal, Masyarakat Samin.

\section{Pendahuluan}

Gerakan sosial yang terjadi di Sukolilo, Pati, Jawa Tengah dalam rangka menolak rencana pemerintah yang akan melakukan pembangunan pabrik semen di Sukolilo, Pati, Jawa Tengah merupakan gerakan sosial yang unik. Gerakan sosial yang sering dikenal dengan sebutan gerakan aksi tolak ini dimulai pada tahun 2006 ketika pemerintah melalui PT Semen Gresik akan mendirikan pabrik semen di Sukolilo. Pada saat itu, masyarakat Samin dan masyarakat non-Samin yang ada di Sukolilo bekerjasama melakukan penolakan terhadap rencana pembangunan pabrik semen.

Yang unik, dalam gerakan aksi tolak ini masyarakat Samin yang selama ini tertutup dan dan meminimalisasi hubungan dengan masyarakat non-Samin yang ada di sekitarnya, ikut terlibat dalam gerakan aksi tolak ini. Dalam perkembangannya, 
masyarakat Samin justru menjadi motivator dan pemimpin dalam gerakan. Interaksi dan relasi yang terjadi antara masyarakat Samin dan masyarakat non-Samin yang ada di Sukolilo selama gerakan aksi tolak, membentuk pola komunikasi dalam gerakan. Pola komunikasi dalam gerakan aksi tolak ini adalah pola komunikasi yang terbentuk berdasarkan kearifan lokal masyarakat Samin. Yang menjadi pertanyaan dan menjadi fokus bahasan dalam tulisan ini adalah "Bagaimana pola komunikasi dalam gerakan aksi tolak di Sukolilo, Pati, Jawa Tengah, berdasarkan kearifan lokal masyarakat Samin?”

Masyarakat Samin merupakan masyarakat adat yang terbentuk sebagai akibat dari gerakan melawan penjajah Belanda. Darmo Subekti (63), seorang budayawan dan mantan Kepala Humas Kabupaten Blora yang pernah duduk dalam tim penyusunan sejarah Kabupaten Blora mengatakan bahwa Saminisme adalah sebuah pergerakan melawan pemerintah Belanda. Pergerakan ini berawal ketika Belanda melakukan pematokan tanah untuk kegiatan penanaman hutan jati tahun 1870 (Sujayanto, 2008). Di bawah kepemimpinan Samin Surosentiko, masyarakat yang ada di sekitar hutan jati yang ada di Ngawi, Cepu, Bojonegoro, Blora dan Pati melakukan perlawanan terhadap penjajah Belanda.

Suripan Sadi Hutomo (1996 : 17) menuliskan, para pengikut Samin menganggap Samin Surosentiko sebagai Ratu Tanah Jawi atau Ratu Adil Heru Cakra dengan gelar Prabu Panembahan Suryangalam. Pengikut Samin ini memiliki pandangan bahwa langkah swastanisasi kehutanan tahun 1875 yang dilakukan oleh Belanda dengan mengambil alih tanahtanah kerajaan, merupakan tindakan yang menyengsarakan masyarakat. Masyarakat menjadi terusir dari tanah leluhurnya. Sebelumnya, pengikut Samin Surosentiko selalu berpendapat bahwa tanah dan udara adalah hak milik komunal yang merupakan perwujudan kekuasaan Tuhan Yang Maha Esa. Pemahaman inilah yang akhirnya membuat mereka menolak berbicara dengan mandor-mandor hutan dan para pengelola dengan bahasa krama. Sebagai gantinya para Saminis memperjuangkan hak-haknya dengan menggunakan bahasa Jawa ngoko yang kasar alias tidak taklim. Sasaran mereka sangat jelas, para mandor hutan dan pejabat pemerintah Belanda. Penggunaan bahasa Jawa ngoko yang kasar merupakan bentuk pemberontakan terhadap pemerintah Belanda.

Dalam perkembangannya, masyarakat yang terbentuk karena gerakan melawan penjajah Belanda ini menjadi sebuah komunitas yang terkenal dengan sebutan masyarakat Samin. Setelah penjajah Belanda pergi dari Indonesia, masyarakat Samin tetap menggunakan bahasa Jawa ngoko dalam kehidupan sehari-hari. Bahasa Jawa yang digunakan oleh masyarakat Samin ini tidak sama dengan bahasa Jawa yang digunakan oleh masyarakat Jawa pada umumnya. Ketika berkomunikasi, masyarakat Samin tidak menggunakan struktur dan tingkatan bahasa seperti bahasa Jawa pada umumnya. Bahasa Jawa Ngoko dan kasar digunakan kepada setiap orang 
yang dia temui tanpa memandang derajat dan pangkat. Tindakan masyarakat Samin ini didasarkan pada pandangan bahwa semua orang mempunyai kedudukan yang sama.

Tindakan masyarakat Samin ini dianggap sebagai tindakan yang kasar dan tidak pada tempatnya, dan membuat pemerintah serta masyarakat menjadi jengkel. Akibatnya, masyarakat dan pemerintah memutuskan untuk meminimalisasi hubungan dengan masyarakat Samin. Penolakan dari pemerintah dan masyarakat, membuat masyarakat Samin menarik diri dari pergaulan dengan masyarakat yang ada di sekitarnya. Hampir sebagian besar aktivitas masyarakat Samin lebih banyak dilakukan dalam lingkup internal dengan berpusat pada pemimpin. Pada tataran ini pemimpin mempunyai peranan yang sangat besar dalam komunitas. Peran sentral pemimpin dalam kehidupan masyarakat Samin ini kemudian membentuk pola komunikasi yang tersentral pada pemimpin (Darmastuti, 2005 : 25). Pola komunikasi ini mengalami perubahan ketika masyarakat Samin mulai berinteraksi dengan masyarakat non-Samin yang ada di Sukolilo dalam gerakan sosial menolak pembangunan pabrik semen yang ada di Sukolilo, Pati, Jawa Tengah.

Menurut Hartini dan Kartasaputra (1992 : 301), pola komunikasi merupakan standarisasi dari kumpulan perilaku. Reading (1986 : 271) mengatakan pola komunikasi sebagai 'pola tingkah laku yang berfungsi sebagai suatu model'. Pola komunikasi sebagaimana lazimnya, selalu mengikuti suatu alur atau kaidah tertentu. Kaidah ini juga yang mengatur gaya berkomunikasi dalam konteks sosial. Hubungan bentuk dan fungsi komunikasi ini yang dinamakan pemolaan komunikasi (communication patterning).

Pola terjadi pada semua tingkat komunikasi, yaitu tingkat komunikasi sosial, kelompok dan individu. Pada tingkat masyarakat, pola komunikasi biasanya terjadi dalam hal fungsi, kategori bicara dan sikap serta konsepsi tentang bahasa dan komunikator. Pola komunikasi ini biasanya disesuaikan dengan peran tertentu yang ada di dalam masyarakat, seperti jenis kelamin, usia, status sosial dan pekerjaan. Sebagai contoh, guru memiliki cara berbicara yang berbeda dengan pengacara, dokter atau salesman asuransi. Cara berbicara juga dipengaruhi dengan tingkat pendidikan, tempat tinggal (pedesaan atau perkotaan), wilayah geografis, organisasi sosial dan lainnya. Seorang guru sebagai anggota suatu kelompok memiliki cara-cara berbicara yang berbeda dengan ahli hukum atau dokter sebagai kelompok lainnya. Di sisi yang lain, komunikasi berpola pada tingkat individual, yaitu pada tingkat ekspresi dan interpretasi kepribadian (Ibrahim, 1992 : 12-13).

Menurut Martin dan Nakayana, budaya mempunyai peran yang sangat besar dalam pembentukan pola komunikasi. 'These cultural value may influence patterns of communication" (Martin dan Nakayama, 2002 : 91). Clifford Geertz (1973 : 89 dalam Martin dan Nakayama, 2003 : 78) memberikan definisi tentang budaya sebagai 
'Culture denotes an historically transmitted pattern of meaning embodied in symbols, a system of inherited conceptions expressed in symbolic forms by means of which men communicate, perpetuate and develop their knowledge about and attitudes toward life'.

Dalam pandangan Geertz, budaya merupakan pola sejarah yang mentransmisikan makna yang melekat dalam simbol-simbol yang digunakan oleh suatu masyarakat. Pada tataran inibudaya menjadi sebuah sistem konsepsi yang diwariskan dari satu generasi kepada generasi berikutnya dalam bentuk simbol-simbol sesuai dengan artinya. Simbol-simbol ini digunakan pada saat mereka berkomunikasi atau pada saat mereka melestarikan dan mengembangkan pengetahuan tentang kehidupan dan bagaimana mereka harus bersikap dalam kehidupan ini.

Philipsen (2002 dalam Martin dan Nakayama, 2003 : 97) mengatakan 'Culture non only influence communication but also is enacted through and so is influenced by communication'. Budaya bukan hanya mempengaruhi komunikasi, tetapi juga dipengaruhi oleh komunikasi. Komunikasi itu lahir karena manusia berpikir dan menyatakan eksistensi dirinya. Sementara eksistensi itu ada karena pengakuan dari manusia lainnya yang ada di sekitarnya. Pengakuan itu lahir karena ada bahasa yang membuat manusia bertukar pikiran, sehingga lahirlah komunikasi. Komunikasi inilah yang membuat manusia bisa berinteraksi dengan manusia lainnya sehingga melahirkan suatu masyarakat. Interaksi antara satu individu dengan individu lainnya di dalam masyarakat mengakibatkan lahirnya budaya (Purwasito 2003: 105).
Ketika berbicara peranan budaya dalam pembentukan pola komunikasi, maka salah satu komponen budaya yang memiliki peran dalam pembentukan pola komunikasi adalah kearifan lokal. Selama ini ada banyak pemahaman tentang kearifan lokal. Kearifan lokal dipahami sebagai cara hidup suatu masyarakat yang didasarkan pada ajaran, ideologi dan falsafah hidup dari suatu budaya. Menurut Rahyono (2009 : 7), kearifan lokal merupakan sebuah kecerdasan yang dimiliki oleh kelompok etnis tertentu yang diperoleh melalui pengalaman etnis tersebut bergulat dengan lingkungan hidupnya. Dalam pandangan Rahyono, kearifan lokal yang dimiliki oleh suatu masyarakat terbentuk sebagai akibat proses yang terjadi dengan lingkungan hidupnya.

Kearifan lokal bukan hanya terbentuk dari proses dengan lingkungannya saja, tetapi juga dari warisan nenek moyang. Suhartini (2009 : 1) mengatakan kearifan lokal merupakan warisan nenek moyang yang berkaitan dengan tata nilai kehidupan. Tata nilai kehidupan ini menyatu tidak hanya dalam bentuk religi, tetapi juga dalam budaya dan adat istiadat. Ketika sebuah masyarakat melakukan adaptasi terhadap lingkungannya, mereka mengembangkan suatu kearifan baik yang berwujud pengetahuan atau ide, peralatan, dipadu dengan norma adat, nilai budaya, aktivitas mengelola lingkungan guna mencukupi kebutuhan hidupnya.

\section{Metode Penelitian}

Artikel ini merupakan bagian dari disertasi dengan judul "Pola Komunikasi 
dan Konstruksi Identitas Masyarakat Samin (Studi Etnografi Komunikasi Dalam Gerakan Sosial Di Sukolilo, Pati, Jawa Tengah)”. Tulisan ini didasarkan pada hasil penelitian yang dilakukan penulis di Sukolilo pada bulan Januari 2014 sampai Desember 2015.

Penelitian ini dilakukan dengan menggunakan pendekatan konstruktivis dan metode etnografi komunikasi. Dalam penelitian ini, peneliti dilakukan pengumpulan data dengan menggunakan metode wawancara mendalam dan observasi secara langsung. Wawancara mendalam dilakukan dengan tokoh-tokoh masyarakat Samin dan masyarakat non-Samin yang ada di Sukolilo yang terlibat dalam gerakan. Observasi dilakukan secara langsung dalam kehidupan masyarakat Samin. Validitas data dilakukan melalui trianggulasi narasumber dan trianggulasi waktu.

\section{Hasil Penelitian dan Pembahasan}

Pandangan Hidup Masyarakat Samin terkait dengan Aksi Tolak

Ada dua alasan yang menjadi dasar ketika masyarakat Samin dan masyarakat non Samin yang ada di Sukolilo melakukan gerakan aksi tolak. Alasan yang pertama adalah mempertahankan profesi mereka sebagai petani, dan alasan yang kedua adalah untuk menyelamatkan dan melestarikan pegunungan Kendeng.

Dalam pandangan masyarakat Samin, profesi sebagai petani merupakan profesi yang sangat mulia dan harus tetap dipertahankan. Hal ini seperti yang dikatakan oleh mbah Tarno dalam wawancara mendalam yang dilakukan oleh penulis pada tanggal 8 Januari 2005, "Tetanen wis dadi uripe sedulur sikep, dagang ora seneng. Dagang iku rak nindakno goroh. Piye ora goroh lha wong kulakane sewu ngomong sewu rongatus. Ingsun oragelemnindake goroh. Yen tetanen sapa kang digorohi?" Maksudnya pertanian sudah menjadi sumber penghidupan yang penting bagi saudara sikep (sebutan mereka untuk masyarakat Samin). Mereka tidak suka berdagang, sebab berdagang itu dianggap sebagai aktivitas yang penuh dengan kebohongan. Bagaimana tidak bohong kalau belinya seribu kemudian meraka bilang ke pembeli seribu dua ratus? Orang Samin mempunyai prinsip tidak mau berbohong. Kalau bertani, siapa yang akan dibohongi? (Darmastuti, 2005 : 79). Profesi sebagai petani, merupakan profesi yang sangat mulia. Ketika profesi mereka sebagai petani terancam, maka masyarakat Samin tidak tinggal diam dan melakukan tindakan untuk mempertahankan profesi tersebut. Lik $\mathrm{Rj}$, salah satu anggota masyarakat Samin yang tinggal di Kedu, dalam wawancara mendalam pada tanggal 10 Maret 2015 mengatakan,

"Panci awale niku ngeten lho, mergi sedulur Sikep niku kan pekerjaane kan panci ting nggarapan, toto nggawuto, dados nek onten pabrik semen dampake ting petani kan nggih enten, sepindah ting tanduran nggih ngrusak, kaping kalih niku kan ting kesehatan".

(Memang awalnya itu seperti ini, karena orang Samin itu pekerjaannya kan ke sawah, bertani, jadi kalau ada pabrik semen dampaknya ke petani ya banyak. Pertama, tanaman akan menjadi rusak. Kedua, akibat ke kesehatan).

Dalam pandangan Lik $\mathrm{Rj}$, sebagai petani masyarakat Samin akan kehilangan 
lahan pertanian ketika lahan tersebut akan dibangun pabrik semen. Kehilangan lahan pertanian, berarti akan kehilangan profesi mereka sebagai petani.

Alasan yang kedua yang menjadi dasar dari gerakan sosial yang dilakukan oleh masyarakat Samin adalah ajaran masyarakat Samin terkait dengan lingkungan. Hal ini seperti yang dikatakan oleh dhe Ic, "Yo bab aksi tolak sing ditindakno dulur Sikep kuwi, sithikake kui maksimal tindakane selisih seko adeg-adeg”. (Ya tentang aksi tolak yang dilakukan oleh masyarakat Samin itu, sedikit banyaknya sangat dipengaruhi oleh pandangan hidup masyarakat Samin). Dalam wawancara mendalam pada tanggal 10 Maret 2015 ini, dhe Ic mengatakan bahwa 'Adeg-adeg'(pandangan hidup) masyarakat Samin terkait dengan lingkungan menjadi dasar yang kuat ketika melakukan gerakan. Dalam pandangan masyarakat Samin, 'Apabila lingkungan terancam, maka terancam juga tatacara Masyarakat Samin'.

Pandangan hidup inilah yang menjadi dasar dalam gerakan aksi tolak di Sukolilo. Setiap anggota masyarakat Samin mempunyai tugas mengingatkan setiap orang supaya mereka tetap menjaga lingkungan. Kelestarian lingkungan dan menjaga bumi pertiwi menjadi satu urgensi. Menjaga bumi merupakan wujud dari tanggungjawab terhadap bumi. Dalam pandangan masyarakat Samin, ketika kita menjaga bumi, maka bumi juga akan menjaga kita. Bumi itu kan artinya ibu yang menghidupi. Prinsip inilah yang membuat masyarakat Samin merasa ikut memiliki tanah dan air serta ikut menjaga tanah dan air dimanapun mereka berada. Menurut mbak Gn, "Kanggone dulur Sikep, 'sak dodokan duwe lemah lan duwe banyu". (Bagi masyarakat Samin, di setiap tempat itu ikut mempunyai tanah dan mempunyai air).

Dalam rangka menjaga lingkungan, tokoh-tokoh masyarakat Samin selalu berusaha menyediakan waktu untuk mengadakan pembicaraan dengan masyarakat Samin lainnya terkait dengan lingkungan. Tujuannya adalah untuk mengingatkan masalah kelestarian lingkungan. Penyadaran dan sosialisasi bukan hanya dilakukan untuk masyarakat Samin saja, tetapi juga ditujukan kepada masyarakat non Samin yang ada di Sukolilo, bahkan untuk pemerintah. Lik Pr dalam wawancara mendalam pada tanggal 4 Februari 2014 mengatakan, "Aksi ki tujuane ngelingno pemerintah" (Aksi itu kan tujuannya untuk mengingatkan pemerintah).

Pola komunikasi dalam gerakan

Gerakan aksi tolak yang dilakukan oleh masyarakat Samin dan masyarakat non Samin yang ada di Sukolilo diawali oleh 'kegelisahan' yang dirasakan oleh mbak Tarno terkait dengan pendirian pabrik semen yang akan mengancam lahan pertanian mereka. 'Kegelisahan' inilah yang kemudian membuat mbah Tarno melakukan tindakan dengan mengumpulkan semua anggota masyarakat Samin di rumahnya dan menjelaskan tentang rencana pemerintah yang akan membangun pabrik semen di daerah Sukolilo. Dalam pertemuan itu, mbah Tarno juga menjelaskan akibat serta bencana yang akan terjadi apabila pabrik semen dibangun di daerah Sukolilo. 
Dalam pertemuan ini mbah Tarno memberi nasihat kepada setiap anggota masyarakat Samin yang hadir supaya tetap mempertahankan pegunungan Kendeng dari ancaman pendirian pabrik semen dan melestarikannya. Dengan semangat untuk menyelamatkan dan melestarikan pegunungan Kendeng, mbah Tarno kemudian mengumpulkan semua anggota masyarakat Samin yang ada di Sukolilo dan mengajak mereka untuk memikirkan keselamatan pegunungan Kendeng. Mbah Wr, salah satu sesepuh masyarakat Samin, dalam sebuah wawancara mendalam mengatakan,

"Nalika Sukolilo diancam semen gersik, mbah Tarno ngendika yen Jawa Tengah iku nek isa ojo dibangun pabrik semen. Malah kudune Jawa Tengah iku dadi lumbung pangan, kanggo masa depan".

(Ketika Sukolilo terancam karena rencana pembangunan semen Gresik, Mbah Tarno berkata kalau Jawa Tengah itu kalau bisa jangan dibangun pabrik semen. Justru seharusnya Jawa Tengah itu jadi lumbung padi, buat masa depan)

Nasihat mbah Tarno untuk menolak pembangunan pabrik semen di Jawa Tengah menjadi pegangan masyarakat Samin dalam melakukan gerakan aksi tolak. Bagi masyarakat Samin, pesan dari sesepuh merupakan tugas yang harus dipegang dan dijalankan. Ketika mbah Tarno memberi pesan 'bukan hanya Pati, tetapi Jawa tengah yang harus dipertahankan', maka semua masyarakat Samin berusaha untuk memperjuangkan tugas yang diberikan kepada mereka. Tugas yang diberikan oleh mbah Tarno untuk mempertahankan Pati dan Jawa Tengah inilah yang kemudian menjadi awal gerakan yang dilakukan oleh masyarakat Samin. Hal ini seperti yang dikatakan oleh mbak Gn dalam wawancara mendalam pada tanggal 19 Maret 2015, "Sak kecap tetembungan kuwi iki kan menehi tugas kanggo anak putu”. (Satu kalimat yang diucapkan mbah No itu merupakan tugas untuk anak cucunya).

Pernyataan mbak Gn ini menunjukkan bahwa pesan yang disampaikan oleh pemimpin merupakan pesan yang sangat penting bagi setiap anggota masyarakat Samin. 'Sak kecap tetembungan kuwi kan menehi tugas kanggo anak putu', bahkan satu pernyataan saja yang disampaikan oleh seorang pemimpin, merupakan tugas yang harus dilakukan oleh setiap anggota, termasuk pesan yang terkait dengan gerakan sosial. Bagi masyarakat Samin, satu pernyataan yang diberikan oleh sesepuh merupakan tugas yang harus dilakukan untuk melanjutkan tatacara orang Samin. Melalui tugas yang diberikan oleh sesepuh kepada setiap anggota masyarakat Samin ini, secara tidak langsung setiap anggota juga diberi tanggung jawab untuk meneruskan pesan ini kepada generasi berikutnya. Nasehat dan pesan dari sesepuh disampaikan secara berantai dari satu generasi kepada generasi berikutnya.

Penyampaian pesan yang berantai ini menunjukkan peran sentral pemimpin dalam peristiwa komunikasi. Selain itu, peran sentral pemimpin ini juga terlihat dalam pertemuan masyarakat Samin yang membahas tentang rencana pemerintah yang akan membangun pabrik semen di Sukolilo. Peran sentral pemimpin dalam peristiwa komunikasi dan dalam 
pertemuan ini membentuk pola komunikasi yang tersentral pada pemimpin. Peran sentral mbah Tarno sebagai pusat dalam komunikasi juga terjadi ketika Sony Keraf, anggota komisi VII DPR-RI berkunjung ke masyarakat Samin dan berusaha menjadi penengah dalam konflik ini. Dalam pertemuan ini, mbah Tarno yang berperan sebagai pemimpin masyarakat Samin (sering disebut dengan sesepuh) menjadi pusat dalam peristiwa komunikasi yang terjadi.

Dalam setiap pertemuan yang dilakukan, mbah Tarno selalu berusaha memberikan nasihat kepada anak cucunya supaya pabrik Semen jangan sampai di bangun di Sukolilo, di sepanjang pegunungan Kendeng dan di Jawa Tengah. Jawa Tengah merupakan pusat dari pulau Jawa, maka perlu diusahakan supaya di Jawa Tengah jangan sampai berdiri pabrik semen. Nasihat dan harapan mbah Tarno ini akhirnya menjadi semangat yang dihidupi oleh semua masyarakat Samin. Pesan yang disampaikan oleh mbah Tarno sebagai pemimpin gerakan, menjadi pesan yang dipegang dan dilakukan oleh semua anggota masyarakat Samin. Pola komunikasi yang terjadi pada awal gerakan ini adalah pola komunikasi yang terpusat pada pemimpin.

Pola komunikasi masyarakat Samin ini mengalami sedikit perubahan ketika terjadi gerakan aksi tolak. Sekalipun pada saat itu mbah Tarno belum meninggal, pola komunikasi yang terbentuk bukan lagi pola komunikasi yang sepenuhnya tersentral pada pemimpin dengan informasi yang bersifat 'the two step flow'. Hal ini terjadi karena dalam gerakan aksi tolak terhadap pembangunan pabrik semen ini, setiap anggota masyarakat Samin mempunyai kesempatan dan peluang untuk berkomunikasi dan berinteraksi dengan masyarakat non-Samin lainnya. Komunikasi eksternal yang terjadi tidak hanya dilakukan oleh pemimpin, tetapi juga dilakukan oleh setiap anggota masyarakat Samin yang ikut dalam gerakan. Hanya saja, komunikasi eksternal yang dilakukan oleh setiap anggota masyarakat yang ikut dalam gerakan tetap berada pada batas-batas tertentu. Masyarakat Samin mempunyai kesepakatan bersama untuk menentukan batas-batas dalam komunikasi eksternal dengan masyarakat non-Samin. Pada tataran ini, pemimpin mempunyai peranan yang sangat besar untuk mengontrol pesan-pesan yang masuk dan keluar dari komunitas ini.

Strategi Komunikasi dalam Gerakan

Masyarakat Samin memiliki pandangan bahwa komunikasi mempunyai peranan yang sangat penting dalam kehidupan, termasuk dalam gerakan aksi tolak. Berdasarkan pemahaman ini, maka strategi yang digunakan dalam gerakan aksi tolak ini lebih menekankan pada strategi komunikasi. Mbak Sm, salah satu anggota masyarakat Samin yang aktif dalam gerakan aksi tolak pembangunan pabrik semen mengatakan, "Informasi masalah gerakan kuwi biasane soko mbak Gn, terus disebarno neng dulur-dulur lewat sms. Seko sms trus disebarno nganggo cara gethok tular". (Informasi masalah gerakan itu biasanya berasal dari Mbak Gn, terus disebarkan 
kepada saudara-saudara lewat sms. Dari SMS kemudian disebarkan dengan cara dari mulut ke mulut). Arus informasi yang terjadi dalam gerakan membentuk pola komunikasi. Terkait dengan kegiatan tolak ini dhe Msl, dalam wawancara mendalam pada tanggal 10 Maret 2015 mengatakan, "Wonten kegiatan tolak, niku nggih wonten gethuk tular kalih konco-konco kersane do semangat ayo bareng-bareng cara wong nyambut gawe." (Terkait dengan kegiatan aksi tolak, informasi itu disampaikan secara langsung dari mulut ke mulut antar teman. Tujuannya adalah supaya semua semangat dan bersama-sama dalam bekerja).

Pola komunikasi eksternal dilakukan melalui salah satu 'opinion leader' yang berasal dari masyarakat Samin. Opinion leader ini kemudian menyampaikan pesan dan informasi yang terkait dengan gerakan kepada masyarakat eksternal di luar masyarakat Samin melalui sms maupun disebarkan dari mulut ke mulut. Masyarakat Samin menyebut strategi ini dengan menggunakan istilah gethok tular. Informasi yang berasal dari mbak Gn yang terkait dengan gerakan disampaikan kepada beberapa anggota masyarakat Samin lainnya melalui sms maupun secara langsung. Dalam gerakan aksi tolak ini, komunikasi yang dilakukan oleh masyarakat Samin merupakan suatu usaha untuk mengajak dan merangkul masyarakat non-Samin dalam rangka melestarikan lingkungan. Hal ini seperti yang dikatakan oleh Lik Pur, “Sikep niku mbelani lingkungan, nggih mboten ngrangkul tapi ngajak mbelani lingkungan kanggo anak putu keri supaya ijek lestari. Tujuanne ngrangkul dulurdulur”. (Masyarakat Samin itu membela lingkungan, ya tidak merangkul dan mempengaruhi, tetapi mengajak masyarakat untuk melestarikan lingkungan untuk anak cucu nanti. Tujuannya merangkul saudara-saudara). Dalam wawancara mendalam yang dilakukan pada tanggal 11 Februari 2015 ini, Lik Pur mengatakan bahwa selama ini masyarakat Samin tidak mempengaruhi masyarakat Sukolilo untuk melakukan gerakan. Masyarakat Samin hanya merangkul dan mengajak masyarakat Sukolilo untuk melestarikan lingkungan, supaya anak cucu masih bisa menikmati lingkungan yang lestari.

Gethok tular (pesan berantai), merupakan salah satu cara yang digunakan oleh masyarakat Samin untuk menyampaikan informasi kepada masyarakat non-Samin yang ada di Sukolilo. Komunikasi dari mulut ke mulut ini merupakan strategi yang sangat efektif untuk mencapai masyarakat lainnya yang ada di Kedu dan di Sukolilo. Strategi penyebaran informasi yang sangat cepat ini digunakan untuk menyampaikan informasi yang terkait dengan kelestarian lingkungan. Hal ini seperti yang dilakukan oleh lik Drt, salah satu masyarakat nonSamin yang terlibat dalam aksi tolak pembangunan pabrik semen. Dalam wawancara mendalam yang dilakukan pada tanggal 10 Maret 2015, Lik Drt mengatakan, "Informasi kuwi yo disebarke nganggo cara gethok tular. Informasi saka mbak Gn, trus disebarke no dulur-dulur liyane nganggo gethok tular" (Informasi itu ya disebarkan dengan cara dari mulut 
ke mulut. Informasi dari Mbak Gn, terus disebarkan ke masyarakat lainnya melalui komunikasi langsung dari mulut ke mulut).

Pola komunikasi yang terjadi dalam kehidupan masyarakat Samin tidak lepas dari budaya yang mereka miliki. Artinya, pola komunikasi yang terjadi dalam kehidupan sehari-hari, sangat dipengaruhi oleh budaya serta kearifan lokal yang dihidupi masyarakat ini. Martin dan Nakayama (2002 : 91) mengatakan, 'These cultural value may influence patterns of communication". Dalam pandangan Martin dan Nakayama, nilai-nilai budaya yang dimiliki oleh suatu masyarakat sangat mempengaruhi pola komunikasi yang terbentuk dalam masyarakat tersebut. Saville-Troike (2003 : 11) menjelaskan pola komunikasi dengan mendefinisikan pola sebagai budaya. Dengan mengacu pada pendapat Du Bois (2000 : 94) SavilleTroike menjelaskan bahwa budaya bisa dipahami sebagai pola yang memberikan makna pada tindakan sosial dan entitas (Du Bois 2000: 94 dalam Saville-Troike, 2003 : 11).

Masyarakat Samin memiliki pola komunikasi yang berbeda dengan masyarakat Jawa pada umumnya. Pola komunikasi masyarakat Samin adalah pola komunikasi yang tersentral pada pemimpin (Darmastuti, 2005 : 26). Pola komunikasi masyarakat Samin mulai mengalami perubahan ketika terjadi aksi tolak terhadap rencana pembangunan pabrik semen di Sukolilo, Pati, Jawa Tengah. Masyarakat Samin dan masyarakat non-Samin yang ada di Sukolilo mempunyai sikap yang sama terhadap rencana pemerintah yang akan membangun pabrik semen di Sukolilo, yaitu sikap menolak. Persamaan sikap inilah yang membuat masyarakat Samin dan masyarakat non-Samin yang ada di Sukolilo melakukan kerjasama dalam melakukan aksi tolak.

Pada tataran ini, terjadi relasi dan interaksi antara masyarakat Samin dan masyarakat non-Samin yang ada di Sukolilo. Interaksi dan relasi yang terjadi selama melakukan gerakan aksi tolak, ternyata mengubah pola komunikasi dalam kehidupan masyarakat Samin.

Sebagai masyarakat yang hidup dengan latar belakang budaya Jawa, pola komunikasi yang terjadi dalam kehidupan masyarakat Samin sangat dipengaruhi oleh budaya Jawa. Dalam pandangan masyarakat Jawa,

"The individual cannot be thought free from those who give birth to and care for him. This fact of being primarily a social creature, of belonging to others and to each other, entails interconnecting obligations. To be a fully grown adult means to become a parent, and parents must care for and teach children. This, in turn, obliges these children to honour their parents, to follow their advice, to be obedient, and, ultimately, to marry" (Mulder, 1994 : 59)

Menurut Mulder, ketika memahami seorang individu maka tidak bisa lepas dari mereka yang melahirkan dan merawatnya. Sebagai makhluk sosial, seorang individu adalah milik orang lain dan sebaliknya dia memiliki orang lain. Artinya antara satu dengan yang lain saling memiliki. Dalam kehidupan masyarakat Jawa, prinsip ini menjadi satu hal yang utama. Akibatnya, ada kewajiban yang saling terkait, yang harus ditanggung oleh seorang individu 
sebagai anggota masyarakat. Seseorang akan dianggap sebagai orang dewasa yang lengkap apabila menjadi orang tua, dan orang tua harus memelihara dan mengajar anak-anaknya. Pada gilirannya, anak-anak akan mempunyai kewajiban untuk menghormati orang tua mereka, mengikuti petunjuknya, patuh dan akhirnya menikah. Penjelasan yang diberikan oleh Mulder ini menunjukkan bahwa seorang individu dalam suatu masyarakat tidak akan bisa lepas dari individu lainnya. Penjelasan ini menunjukkan bahwa dalam pandangan masyarakat Jawa, seorang individu adalah bagian dari masyarakat dan menjadi milik masyarakat. Sebaliknya, seorang individu juga memiliki masyarakat tersebut.

Seorang individu yang hidup dalam suatu masyarakat Jawa, harus bertanggung jawab dan mengambil peran untuk mewujudkan cita-cita masyarakat tempat dia berada. Cita-cita hidup orang Jawa adalah untuk mewujudkan keselarasan dan keserasian dalam rangka menciptakan hidup rukun. Kerukunan tidak datang sebagai suatu pemberian atau sesuatu yang datang dengan sendirinya, tetapi merupakan hasil dari kemauan aktif untuk saling menghormati dan saling menyesuaikan diri (Saksono dan Dwiyanto, 2012 : 165). Clifford Geertz (1981: 156) mengatakan, "Hidup rukun adalah kemampuan untuk hidup bersama secara damai dan membantu kemajuan satu sama lain dalam jaman baru". Melalui rukun dan hormat, orang semakin arif dalam komunikasi antarpersonal dalam masyarakat, hingga jauh dari ketegangan sosial (Endraswara, $2010: 61)$.
Prinsip hidup orang Jawa untuk mewujudkan keselarasan dan keserasian yang teraplikasi melalui hidup rukun dan hormat menjadi dasar dalam melakukan gerakan aksi tolak secara damai dan tanpa kekerasan. Strategi komunikasi menjadi strategi yang digunakan untuk melakukan gerakan aksi tolak secara damai dan tanpa kekerasan. Strategi komunikasi yang dilakukan secara terus menerus akhirnya membentuk pola komunikasi dalam gerakan aksi tolak. Pola komunikasi masyarakat Samin yang pada awalnya berpusat pada pemimpin, mengalami perubahan menjadi pola komunikasi melalui opinion leader.

Sebelum terjadi gerakan aksi tolak, pola komunikasi masyarakat Samin adalah pola komunikasi yang tersentral pada pemimpin yang didasari oleh prinsip hidup rukun. Prinsip kerukunan bertujuan untuk mempertahankan masyarakat dalam keadaan yang harmonis. Rukun berarti 'berada dalam keadaan selaras', 'tenang dan tentram', 'tanpa perselisihan dan pertentangan', 'bersatu dalam maksud untuk saling membantu' (Magnis-Suseno, 1993 : 39). Setelah terjadi gerakan aksi tolak, sekalipun pola komunikasi mengalami perubahan, tetapi pola komunikasi yang terjadi tetap didasarkan pada prinsip rukun. Dalam aksi tolak terhadap rencana pembangunan pabrik semen ini, kondisi 'rukun' menjadi modal utama untuk keberhasilan gerakan ini. Keadaan rukun merupakan keadaan dimana semua pihak berada dalam keadaan damai satu sama lain, suka bekerja sama, saling menerima dalam suasana tenang dan sepakat (MagnisSuseno, $1993: 39$ ). 
Pada awalnya, pola komunikasi dalam gerakan ini terjadi karena ada masyarakat non-Samin yang datang kepada masyarakat Samin dan mengeluh terhadap rencana pemerintah yang akan mendirikan pabrik semen. Melihat hal ini, masyarakat Samin tidak tinggal diam. Masyarakat Samin mulai memikirkan tindakan apa yang harus diambil untuk mencegah rencana pemerintah yang akan mendirikan pabrik semen di Sukolilo. Berawal dari kejadian ini, kemudian masyarakat Samin mulai merangkul masyarakat non-Samin dan mengajak mereka melakukan gerakan aksi tolak. Masyarakat Samin mempunyai peranan yang sangat besar dalam penyebaran informasi. Sumber informasi biasanya berasal dari masyarakat Samin, kemudian diteruskan ke opinion leader dan dilanjutkan ke masyarakat non-Samin. Tidak jarang yang bertugas sebagai opinion leader ini juga masyarakat Samin.

Gethok tular (pesan berantai), merupakan salah satu cara yang digunakan oleh masyarakat Samin untuk menyampaikan informasi kepada masyarakat non-Samin yang ada di Sukolilo. Komunikasi dari mulut ke mulut ini merupakan strategi yang sangat efektif untuk mencapai masyarakat lainnya yang ada di Kedu dan di Sukolilo. Strategi penyebaran informasi yang sangat cepat ini digunakan untuk menyampaikan informasi yang terkait dengan kelestarian lingkungan. Proses komunikasi yang dilakukan secara informal ini, menjadi cara yang sangat efektif untuk menyebarkan pesan kepada masyarakat eksternal. Mbak Jtm, salah satu anggota masyarakat non-
Samin yang terlibat dalam gerakan aksi tolak pembangunan pabrik semen ini mengatakan informasi dalam gerakan itu disebarkan secara gethok tular. Dalam wawancara mendalam ini mbak Jtm mengatakan, "Ngangge gethok tular, gethok tular" (Menggunakan komunikasi langsung dari mulut ke mulut).

Gethok tular tidak hanya dilakukan oleh orang dewasa, tetapi juga dilakukan oleh anak-anak. Informasi yang terkait dengan aksi tolak pembangunan pabrik semen itu tidak selalu didapat oleh orang tua. Dalam beberapa kasus, justru anak-anak yang mendapatkan informasi tentang rencana pembangunan pabrik semen dan tindakan-tindakan yang dilakukan oleh pabrik semen. Anak-anak yang mendapatkan informasi ini, kemudian menyampaikan informasi ini kepada orang tua mereka masing-masing. Terkait dengan hal ini, Lik Drt mengatakan, "Iyo, dadine cah cilik-cilik ugo langsung laporan wong tuwane ngko kan wong tuwane do ngoyak". (Iya, anak-anak kecil yang mendapatkan informasi tentang pembangunan pabrik semen itu, kemudian langsung lapor ke orang tua masing-masing. Kemudian orang tua mereka yang akan bertindak). Keterlibatan dan beban untuk mempertahankan lingkungan dalam gerakan aksi tolak ini bukan hanya dirasakan oleh orang tua, tetapi juga dirasakan oleh anak-anak. Hal ini terbukti dari tindakan yang dilakukan anak-anak untuk menginformasikan perkembangan yang ada kepada orang tuanya.

Gethok tular (pesan berantai) merupakan komunikasi yang dilakukan secara informal dalam rangka menyampaikan pesan dari 
mulut ke mulut. Strategi komunikasi ini digunakan oleh masyarakat Samin untuk menyampaikan informasi kepada masyarakat non-Samin yang ada di Sukolilo. Strategi komunikasi Gethok tular merupakan salah satu strategi komunikasi dalam gerakan sosial yang terbentuk sebagai aplikasi dari kearifan lokal suatu masyarakat. Pola komunikasi Gethok tular dalam gerakan aksi tolak dapat digambarkan seperti gambar dibawah ini,

Gambar pola komunikasi Gethok tular dalam gerakan aksi tolak diatas menjelaskan alur yang terjadi mulai dari gerakan aksi tolak sampai terbentuknya model komunikasi gethok tular. Gerakan aksi tolak terhadap rencana pemerintah yang akan membangun pabrik semen di Sukolilo, Pati, Jawa Tengah membangun interaksi dan relasi antara masyarakat Samin dan masyarakat Samin yang ada di Sukolilo. Interaksi dan relasi yang terbangun antara masyarakat Samin dan masyarakat non Samin yang ada di Sukolilo sangat dipengaruhi oleh budaya masyarakat Samin. Dalam perkembangannya, budaya masyarakat Samin ini menjadi dasar dalam gerakan aksi tolak, sehingga aksi-aksi yang

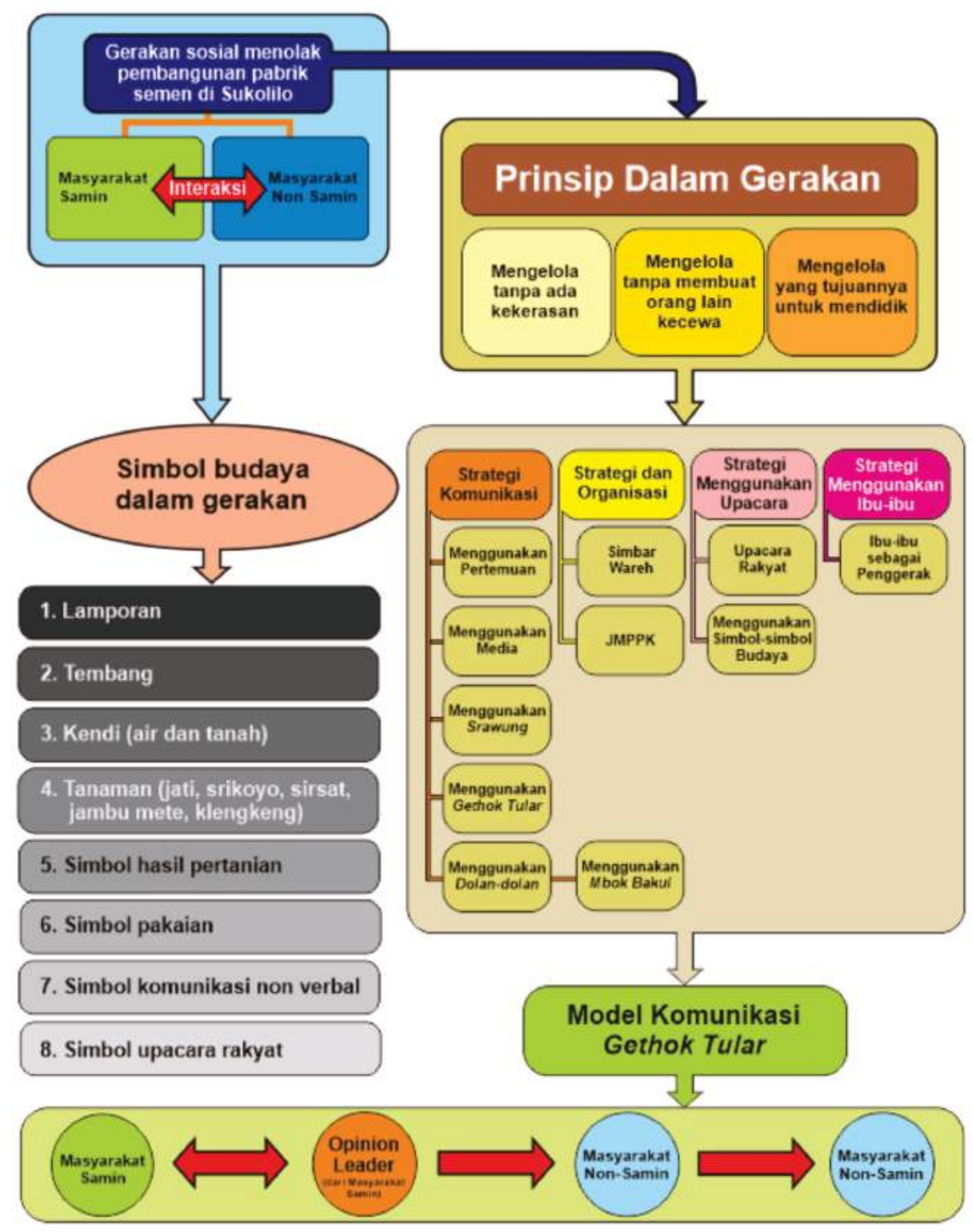

Gambar Pola komunikasi Gethok tular dalam gerakan 'aksi tolak' yang dilakukan masyarakat Samin (Sumber : Darmastuti, 2016 : 591). 
dilakukan dalam gerakan aksi tolak ini lebih banyak dilakukan dengan menggunakan simbol-simbol budaya. Lamporan, tembang, kendi, tanaman (jati, srikoyo, klengkeng), hasil pertanian, simbol pakaian dan upacara rakyat merupakan simbol-simbol budaya yang digunakan dalam gerakan. Simbolsimbol ini menjadi cara untuk menyampaikan pesan dalam gerakan.

Disisi yang lain, gerakan aksi tolak ini dilakukan dengan prinsip mengelola tanpa ada kekerasan, mengelola tanpa membuat orang lain kecewa dan mengelola dengan prinsip mendidik. Berdasarkan prinsip ini, kemudian masyarakat Samin dan masyarakat non Samin yang ada di Sukolilo menggunakan beberapa strategi dalam gerakan. Strategi tersebut adalah strategi komunikasi, strategi dengan menggunakan organisasi, strategi dengan menggunakan upacara dan strategi dengan menggunakan ibu-ibu. Salah satu strategi komunikasi yang digunakan dalam gerakan ini adalah strategi komunikasi gethok tular. Strategi komunikasi gethok tular adalah strategi komunikasi yang dilakukan secara berantai. Komunikasi dari masyarakat Samin ke masyarakat non Samin dilakukan melalui opinion leader dan kemudian secara berantai pesan itu disampaikan kepada masyarakat non Samin lainnya. Dari masyarakat non Samin, pesan itu diteruskan kepada masyarakat non Samin lainnya yang ada di Sukolilo.

Pola komunikasi gethok tular merupakan pola komunikasi yang sangat efektif untuk menyampaikan pesan baik itu ke pihak internal masyarakat Samin maupun kepada masyarakat non Samin yang ada di Sukolilo. Pola komunikasi gethok tular merupakan pola komunikasi, dimana pesan disampaikan secara informal dengan pendekatan secara personal. Pola komunikasi ini terbentuk sebagai dampak dari interaksi dan relasi yang terjadi antara masyarakat Samin dengan masyarakat non Samin yang ada di Sukolilo. Dengan menggunakan kearifan lokal masyarakat Samin yang menekankan pada pendekatan secara personal dan informal, maka terbentuk pola komunikasi gethok tular.

\section{Simpulan}

Gerakan sosial dalam rangka menolak pembangunan pabrik semen di Sukolilo, Pati, Jawa Tengah membangun interaksi dan relasi antara masyarakat Samin dengan masyarakat non Samin yang ada di Sukolilo. Interaksi dan relasi antara masyarakat Samin dan masyarakat non Samin ini dalam perkembangannya memunculkan simbol-simbol budaya yang digunakan dalam gerakan berdasarkan kearifan lokal masyarakat Samin. Disisi yang lain, gerakan aksi tolak yang didasarkan pada prinsip mengelola tanpa ada kekerasan, mengelola tanpa membuat orang lain kecewa dan mengelola dengan prinsip mendidik ini mempengaruhi strategi yang digunakan dalam gerakan.

Masyarakat Samin merupakan masyarakat yang sangat menyadari pentingnya komunikasi. Salah satu strategi yang digunakan dalam gerakan aksi tolak ini adalah strategi komunikasi. Dengan berdasarkan pada kearifan lokal yang mereka miliki, serta berdasarkan pada budaya Jawa yang menekankan pada keselarasan 
dan keserasian yang teraplikasi melalui hidup rukun dan hormat, maka gethok tular menjadi salah satu strategi komunikasi yang digunakan dalam gerakan. Gethok tular merupakan strategi komunikasi untuk menyampaikan pesan secara berantai. Strategi komunikasi gethok tular merupakan strategi komunikasi yang dilakukan secara informal dengan pendekatan secara personal.

Strategi komunikasi gethok tular merupakan strategi komunikasi dalam gerakan sosial yang terbentuk berdasarkan kearifan lokal masyarakat Samin. Melalui strategi komunikasi gethok tular ini, dapat ambil kesimpulan bahwa strategi komunikasi dalam suatu gerakan sosial dapat dilakukan dengan berdasarkan kearifan dan budaya masyarakat tersebut.

\section{Daftar Pustaka}

Darmastuti, Rini. (2005). Pola Komunikasi Sosial Masyarakat Samin (Studi Di Lingkungan Komunitas Di Sukolilo, PatiJawa Tengah). Tesis. Surakarta : Program Pasca Sarjana Universitas Sebelas Maret.

\section{(2005). "Pola Komunikasi} Masyarakat Samin, Khususnya Komunitas di Sukolilo, Pati”. Jurnal Kritis, Jurnal Studi Pembangunan Interdisipliner, Vol. XVII, No. 1, April 2005, hal 59-83. ISSN $0215-4765$. (2016). Pola Komunikasi dan Konstruksi Identitas Masyarakat Samin (Studi Etnografi Komunikasi dalam Gerakan Sosial di Sukolilo, Pati, Jawa Tengah). Disertasi. Bandung : Universitas Padjajaran.

Endraswara, Suwardi. (2010). Etika Hidup orang Jawa. Yogyakarta : Penerbit Narasi.
Geertz, Clifford.(2013).AgamaJawa:Abangan, Santri, Priyayi dalam Kebudayaan Jawa. Depok : Komunitas Bambu.

Hutomo, Suripan Sadi. (1996). Tradisi dari Blora. Semarang: Citra Almamater

Ibrahim, Abd. Syukur. (1992). Panduan Penelitian Etnografi Komunikasi. Surabaya: Penerbit Usaha Nasional

Martin, Judith $\mathrm{N}$ and Thomas K Nakayama. (2003). Intercultural Communication in Contexts. $3^{\text {rd }}$ editions. California : Mayfield.

Purwasito, Andrik. 2003. Komunikasi Multikultural. Surakarta: Muhammadiyah University Press.

Rahyono, FX. (2009). Kearifan budaya dalam kata. Jakarta : Wedatama Widyasastra.

Saksono, Gatut dan Djoko Dwiyanto. (2012). Faham Keselamatan dalam Budaya Jawa. Yogyakarta : Ampera Utama.

Saville-Troike, Muriel. (2003). The Ethnography of Communication : an Introduction. $3^{\text {rd }}$ ed. Blackwell Publishing.

Subekti, Darmo. (1999). Tradisi Lisan Pergerakan Samin, Legitimasi Arus Bawah Menentang Penjajah. (makalah)

Suhartini. (2009). Kajian Kearifan Lokal Masyarakat dalam Pengelolaan Sumberdaya Alam dan Lingkungan. http :// staff.uny.ac.id

Sujayanto, G. dan Mayong S. Laksono. (2008). "Samin: Melawan Penjajah Dengan Jawa Ngoko”. http://www. desantara.or.id/2008/04/saminmelawan-penjajah-dengan-jawa-ngoko/ akses 3 Agustus 2015.

Suseno, Frans Magnis. (1993). Etika Jawa : Sebuah Analisa Falsafi tentang Kebijaksanaan Hidup Jawa. Jakarta : Gramedia Pustaka Utama. 